\title{
ЕЛЕМЕНТНИЙ СКЛАД ЕКВІВАЛЕНТА СТРОМИ РОГІВКИ, ОТРИМАНОЇ МЕТОДОМ ДЕЦЕЛЮЛЯРИЗАЦІї
}

Вступ. У результаті збільшення військового, дорожньо-транспортного і побутового травматизму проблема дефіциту донорського матеріалу особливо актуальна. Величезний дефріцит донорського матеріалу для кератопластики змушує шукати додаткові джерела трансплантаційного матеріалу, методики виготовлення та використання ксеногенних трансплантатів. Одним з таких матеріалів є рогівка свині, яка за своєю структурою і біомеханічними параметрами має схожість з рогівкою людини.

Мета дослідження - вивчити елементний склад еквівалента строми рогівки, видаленої з очей свиней та отриманої методом децелюляризації з метою подальшої можливості ї̈ застосування як матеріалу для кератопластики.

Методи дослідження. Рогівкову оболонку, одержану з видалених очей свиней, розміщують у середовищі для культивування тканини, після чого проводять ї̈ децелюляризацію. Обробляють 0,5 \% розчином додецилсульфрату натрію при постійному струшуванні; обробляють ультразвуком (тричі), проводять інкубацію за наявності ензимного розчину папаїну; промивають буфрерним розчином (pH 6,5), чентрифругують. Поміщають у розчин полівінілпіролідону для зберігання. 3 метою визначення елементного складу біологічних зразків у роботі використали фоотоколориметричний та атомно-абсорбційний методи аналізу.

Результати й обговорення. Досліджено елементний склад еквівалента строми рогівки, отриманої методом децелюляризації. За результатами атомно-абсорбційного аналізу, в децелюляризованій рогівці свиней ідентифріковано 14 макро- та мікроелементів. Серед макроелементів найбільшою була кількість натрію - 8323 мг/кг повітряно-сухої проби, калію - 1163 мг/кг, магнію - 618 мг/ка, кальцію - 224 мг/ка. Масова частка мікроелементів у досліджуваному об'єкті перебувала в такій послідовності: залізо 755 мг/ке, кобальт - 296 мг/кг, нікель - 103 мг/кг, титан - 13,2 мг/кг, цинк - 7,9 мг/кг, манган - 4,5 мг/ка, силіцій - 6,2 мг/ке, купрум - 5,7 мг/ке, лантан - 0,4 мг/ке. Найменшою була кількість срібла - 0,03 мг/ке.

Висновок. Перспективними для подальших досліджень $є$ всебічне вивчення та вдосконалення використаного методу децелюляризації рогівки тварин з метою отримання біоінженерних зразків для їх подальшої кератопластики, що дозволить вирішити актуальну проблему трансплантології - отримання донорського матеріалу.

КЛЮчОВІ СЛОВА: рогівка свиней; децелюляризація; макро- та мікроелементи; атомно-абсорбційний метод аналізу; кератопластика.

ВСТУП. Захворювання рогівки є другою причиною сліпоти в більшості країн світу, що розвиваються. На сьогодні, незважаючи на прогрес у наших знаннях про етіопатогенез різних захворювань передньої частини ока, захворювання рогівки вважають основною причиною втрати зору [1, 2].

Рогівка - це прозора передня поверхня ока, яка забезпечує приблизно дві третини його фрокусної сили. Будь-яка постійна втрата прозорості внаслідок травмування або захворювання може призвести до сліпоти. Всесвітня організація охо-

(с) М. Б. Данилюк, І. М. Кліщ, І. П. Кузьмак, А. П. Краснопьорова, 2021. рони здоров'я виявила 23 мільйони людей по всьому світу, які страждають від захворювань рогівки, що призводять до часткової, а в 10 мільйонів - до повної втрати зору на одному чи обох очах. При цьому на рік у світі проводять лише від 100 до 200 тисяч пересадок рогівки. Таким чином, у світі існує значний десріцит донорських рогівок для пересадки. У західних країнах існує відносний дефіцит донорських рогівок, але у країнах, що розвиваються, спостерігають майже повну їх відсутність. Такі хвороби, як трахома, травми й опіки рогівки, кір та бактеріальні інфекції, є провідними причинами сліпоти, яку можна вилікувати шляхом пересадки 
рогівки. В Україні щорічно потрібно приблизно 4000 рогівок для пересадки, тоді як на рік виконують лише близько 500 пересадок рогівки [3, 4].

Трансплантація донорської рогівки людини, а саме кератопластика, $є$ основою для лікування рогівкової сліпоти. Проте глобальний дефіцит донорської рогівки залишає близько 12,7 мільйона осіб у списках очікування, при цьому лише 1 із 70 пацієнтів лікується [2, 5].

Однак застосування такого радикального лікування, як кератопластика, ускладнюється ризиком відторгнення при антигенній несумісності між трансплантатом і господарем та через низьку доступність адекватного донорського матеріалу, тому розробка альтернатив донорській рогівці людини має велике значення $[2,6]$.

У зв'язку з цим, важливо розглянути можливість використання рогівки свині як ксенотрансплантата для людини, оскільки вона найбільше нагадує рогівку людини щодо антигенного складу тканин [6-8].

В останні роки проведено експериментальні дослідження потенційних можливостей застосування для кератопластики рогівки свині як такої, що за своїми морфологічними й імунологічними властивостями достатньо наближена до рогівки людини $[9,10]$.

Важливим $€$ те, що після децелюляризації ксенотрансплантат повинен бути подібним до нативної рогівки людини щодо імунологічної характеристики, біосумісності, механічної міцності та прозорості, створюючи таким чином оптимальне мікроекспериментальне досліджуване середовище для подальшої міграції стромальних і епітеліальних клітин.

Тому розробка та вдосконалення методів для децелюляризації донорської рогівки з метою розвитку біоінженерних моделей рогівки 3 наступною кератопластикою $€$ завданням, що дозволить вирішити актуальну проблему трансплантології - отримання донорського матеріалу [2, 6-13].

Оскільки на даний час не існує надійного, стандартизованого протоколу децелюляризації рогівки людини, наявність зазначених проблем зумовила актуальність проведеного дослідження та визначила мету цієї роботи.

Мета дослідження - вивчити елементний склад еквівалента строми рогівки, видаленої 3 очей свиней та отриманої методом децелюляризації з метою подальшої можливості її застосування як матеріалу для кератопластики.

МЕТОДИ ДОСЛІДЖЕННЯ. Технологія отримання донорського матеріалу була стандартною. Забір рогівок проводили в цеху забою тварин 3 дотриманням принципів біоетики відповідно до
Загальних етичних принципів експериментів на тваринах (Київ, 2001), узгоджених з положеннями Європейської конвенції про захист хребетних тварин, що використовуються для дослідних та інших наукових цілей (Страсбург, 1986), і Директиви Європейського Союзу 2010/10/63 ЕU щодо експериментів на тваринах, а також Науково-практичних рекомендацій з утримання лабораторних тварин та роботи з ними [14].

Рогівкову оболонку, отриману з видалених очей свиней, розміщують у середовищі для культивування тканини, після чого проводять її децелюляризацію таким чином: обробляють 0,5\% розчином додецилсульсрату натрію за умов постійного струшування при температурі, не вищій $4^{\circ} \mathrm{C}$, потім - ультразвуком (використовують ультразвуковий диспергатор УЗДН-М 750) протягом 5 хв, здійснюють інкубацію за наявності ензимного 0,1\% розчину папаїну ( $\mathrm{pH} 6,5)$ упродовж 2,5 год при $30^{\circ} \mathrm{C}$, промивають у калій-сроссратному 0,1 м бусрері $(\mathrm{pH} 6,5)$ трикратно по 5 хв. Знову обробляють ультразвуком протягом 5 хв, потім - 0,5 \% розчином додецилсульфрату натрію двічі впродовж 3 год, промивають у калій-фоссратному 0,1 м бусрері (pH 6,5) трикратно по 5 хв. Ще раз обробляють ультразвуком протягом 5 хв, промивають у калійфоссратному бусрері (pH 6,5) п'ятикратно по 5 хв. Центрифугують (ROTOFIX 32-A) при $3000 \mathrm{~g} 15$ хв 3 декантацією трикратно і переносять у середовище для зберігання - у $2 \%$ розчин полівінілпіролідону при температурі $0{ }^{\circ} \mathrm{C}$ (пат. 101707 U, 2015) [15].

3 метою проведення хімічного аналізу проби рогівки ока забирали шматочки рогівки. Для подальших досліджень використано фрізичні, хімічні й фрізико-хімічні методи аналізу.

Для визначення елементного складу біологічних зразків у роботі застосовано фотоколориметричний та атомно-абсорбційний методи аналізу [16-18].

3 метою визначення хімічного складу біологічних зразків проведено підготовку проб. Пробопідготовку зразків сировини здійснювали методом сухого та мокрого (для визначення кадмію і плюмбуму) озолення [19]. Сухе озолення досліджуваної проби проводили шляхом спалювання у мусрельній печі за температури $450-500{ }^{\circ} \mathrm{C}$ упродовж 5-8 год. Мокре озолення полягає в обробці певної наважки сировини концентрованою сірчаною кислотою і біхроматом калію. У наважку повітряно-сухої проби 0,1 г додавали $10 \%$ розчин біхромату калію та обробляли під тягою 5-10 мл концентрованої сірчаної кислоти, кип'ятили доти, поки розчин не стане прозорим. Це буде свідчити про те, що вся органіка окиснилась (згоріла). Одержаний розчин висушували 
в сушильній шафрі, розчиняли у невеликій кількості води, використовували для подальшого аналізу і, згідно з методиками атомно-абсорбційного або фротоколориметричного аналізу, вимірювали елементи. Атомно-абсорбційний аналіз проводили на атомно-абсорбційному спектросротометрі AA-7050 (EWAI 3 автоматичним перемиканням режимів атомізації).

Атомізацію хімічних елементів здійснювали у повітряно-ацетиленовому полум'ї, аналітичний сигнал вимірювали при таких довжинах хвиль: $\lambda=766,0$ нм (калій), $\lambda=422,0$ нм (кальцій), $\lambda=589,0$ нм (натрій), $\lambda=372,0$ нм (залізо), $\lambda=324,7$ нм (мідь), $\lambda=285,2$ нм (магній), $\lambda=279,5$ нм (марганець), $\lambda=213,9$ нм (цинк), $\lambda=283,3$ нм (свинець), $\lambda=232,0$ нм (нікель), $\lambda=228,8$ нм (кобальт, кадмій), $\lambda=193,1$ нм (миш'як, хром, срібло).

Вміст ртуті у пробах рогівки визначали атомно-абсорбційним методом безполуменевої атомізації за допомогою ртутної приставки ПР-115. Метод полягає у розкладанні ртуті в суміші кислот з подальшим відновленням хлоридом олова й аналізом безполуменевим методом холодної пари на атомно-абсорбційному спектрофотометрі. Використовували аналітичну лінію ртуті 257,7 нм, що відповідала резонансному поглинанню парів. Аналітичний сигнал ртуті вимірювали при довжині хвилі $\lambda=253,7$ нм [20].

Концентрацію титану, лантану, кремнію визначали фоотоколориметричним методом [21, 22].

Оптичну щільність розчину титану вимірювали на спектрофотометрі СФ-46 при довжині хвилі $\lambda=385,0$ нм.

Оптичну густину кремнію вимірювали на спектрооротометрі ФЕК-2. Максимум оптичної густині в спектрі поглинання утвореної сполуки спостерігають при 410 нм [22].

Калібрувальну криву будували в залежності середніх значень поглинання розчинів порівняння солей металів від їх концентрації. Для кожного елемента було досягнуто строгої лінійності 3 використанням п'яти калібрувальних розчинів в інтервалі вимірюваних концентрацій. Максимальна відносна похибка вимірювання при довірчій імовірності 0,95 і п'яти паралельних вимірюваннях становила $\pm 5 \%$ [19].

РЕЗУЛЬТАТИЙ ОБГОВОРЕННЯ. ОТРИМаНИЙ розчин рогівки було досліджено на вміст макрота мікроелементів $\mathrm{Na}, \mathrm{K}, \mathrm{Ca}, \mathrm{Mg}, \mathrm{Fe}, \mathrm{Cu}, \mathrm{Hg}, \mathrm{Pb}$, $\mathrm{Mn}, \mathrm{Cd}, \mathrm{Ni}, \mathrm{Co}, \mathrm{As}, \mathrm{Cr}, \mathrm{Zn}, \mathrm{Si}, \mathrm{Ag}$, Ti, La методом атомно-абсорбційної спектроскопії.

Як відомо, значна кількість порушень гомеостазу пов'язана з дефріцитом або надлишком того чи іншого елемента. Недостатня кількість макрота мікроелементів в організмі зумовлює різно- манітні перетворення у тканинах очного яблука $[23,24]$.

За результатами атомно-абсорбційного аналізу, в децелюляризованій рогівці свині ідентиоріковано 14 макро- та мікроелементів (табл.).

Серед макроелементів найбільшою була кількість натрію - 8323 мг/кг повітряно-сухої проби, калію - 1163 мг/кг, магнію - 618 мг/кг, кальцію - 224 мг/кг.

Масова частка мікроелементів у досліджуваному об'єкті перебувала в такій послідовності: залізо - 755 мг/кг, кобальт - 296 мг/кг, нікель 103 мг/кг, титан - 13,2 мг/кг, цинк - 7,9 мг/кг, манган - 4,5 мг/кг, силіцій - 6,2 мг/кг, купрум - 5,7 мг/кг, лантан - 0,4 мг/кг.

Найменшою була кількість ультрамікроелемента срібла - 0,03 мг/кг.

Не визначено таких мікроелементів: ртуті, свинцю, кадмію, миш'яку, хрому.

Усі біохімічні процеси в організмі регулюються ензимами, а ті, у свою чергу, фрункціонують при наявності активаторів, роль яких частково відіграють такі елементи, як калій, натрій, магній, цинк, алюміній та інші, які у вигляді іонів входять до складу активного центру ензимів, збільшуючи швидкість біохімічних процесів, що регулюють метаболізм.

Так, іони калію входять до активного центру ензимів, що беруть участь у метаболічних процесах, - АТФ-ази, піруваторосорокінази, карбоангідрази тощо [23-25].

Калій, кальцій і хлор є важливими елементами, які беруть участь у регуляції та балансі

Таблиця - Хімічний аналіз проби рогівки ока на вміст макро- і мікроелементів

\begin{tabular}{|c|c|c|}
\hline № 3/ח & Назва показника & Вміст, мг/кг \\
\hline 1 & Натрій (Na) & 8323 \\
\hline 2 & Калій $\left(\mathrm{K}^{+}\right)$ & 1163 \\
\hline 3 & Кальцій (Ca) & 224 \\
\hline 4 & Магній (Mg) & 618 \\
\hline 5 & Залізо (Fe) & 755 \\
\hline 6 & Мідь (Cu) & 5,7 \\
\hline 7 & Ртуть (Hg) & $\mathrm{H} / \mathrm{B}$ \\
\hline 8 & Свинець (Pb) & $\mathrm{H} / \mathrm{B}$ \\
\hline 9 & Марганець (Mn) & 4,5 \\
\hline 10 & Кадмій (Cd) & $\mathrm{H} / \mathrm{B}$ \\
\hline 11 & Нікель (Ni) & 103 \\
\hline 12 & Кобальт (Со) & 296 \\
\hline 13 & Миш'як (As) & $\mathrm{H} / \mathrm{B}$ \\
\hline 14 & Хром (заг.(Cr)) & $\mathrm{H} / \mathrm{B}$ \\
\hline 15 & Цинк (Zn) & 7,9 \\
\hline 16 & Кремній (Si) & 6,2 \\
\hline 17 & Срібло (Ag) & 0,03 \\
\hline 18 & Титан (Ті) & 13,2 \\
\hline 19 & Лантан (La) & 0,4 \\
\hline
\end{tabular}

Примітка. н/в - не визначено. 
негативного або позитивного заряду рогівки i можуть впливати на взаємодії молекул рогівкового матриксу. Можливі зміни розвитку в іонному середовищі $\mathrm{Cl}, \mathrm{K}$ і Са лежать в основі змін у фрізико-хімічній архітектурі рогівки, а також допомагають зробити тканину рогівки прозорою. Встановлено, що з віком та при катаракті в тканинах кришталика зменшується концентрація іонів калію [25].

Мікроелементи алюміній, титан і силіцій беруть участь в утворенні епітеліальних тканин та мембран клітин, надають їм щільності. Купрум, цинк і залізо проявляють синергічну дію один щодо одного, беруть активну участь в окисно-відновних процесах організму та мають антирадикальну активність. Встановлено інгібуючу дію срібла відносно біологічної активності мікроорганізмів [24].

Кератоцити - основні клітинні компоненти строми рогівки - відіграють значну роль у підтриманні прозорості рогівки, відновленні ії при

\section{СПИСОК ЛІТЕРАТУРИ}

1. Oliva M. S. Turning the tide of corneal blindness / M. S. Oliva, T. Schottman, M. Gulati // Indian J. Ophthalmol. - 2012. - 60, Issue 5. - P. 423-427. DOI: $10.4103 / 0301-4738.100540$.

2. Pasyechnikova N. V. Experimental study of efficacy of intralamellar keratoplasty with corneal stromal substitute developed from decellularized porcine cornea / N. V. Pasyechnikova, B. M. Cogan, S. G. Kolomiichuk // J. Ophthalmol. (Ukraine). - 2017. - No. 3. - P. 48-55.

3. Турчин М.В.Експериментальне обґрунтування і досвід використання ксенорогівки при лікувально-тектонічній кератопластиці у хворих із виразками рогівки різної етіології / М. В. Турчин, Н.В.Пасєчнікова // Шпитальна хірургія. Журн. імені Л. Я. Ковальчука. 2017. - № 3. - C. 43-48.

4. LiQD Cornea: Pro-regeneration collagen mimetics as patches and alternatives to corneal transplantation / C. D. McTiernan, F. C. Simpson, M. Haagdorens [et al.] // Sci. Adv. - 2020. -6, Issue 25. - eaba2187. DOI: 10.1126/ sciadv.aba2187.

5. Global survey of corneal transplantation and eye banking / P. Gain, R. Jullienne, Z. He [et al.] // JAMA Ophthalmol. - 2016. - 134, Issue 2. - P. 167-173. DOI: 10.1001/jamaophthalmol.2015.4776.

6. Cox A. Current advances in xenotransplantation / A. Cox, R. Zhong // Hepatobiliary Pancreat. Dis. Int. 2005. - 4, Issue 4. - P. 490-494.

7. Hara H. Xenotransplantation - the future of corneal transplantation? / H. Hara, D. K. Cooper // Cornea. 2011. - 30, Issue 4. - P. 371-378. DOI: 10.1097/ ICO.0b013e3181f237ef.

8. Corneal decellularization: a method of recycling unsuitable donor tissue for clinical translation? I S. L. Wilson, L. E. Sidney, S. E. Dunphy [et al.] // Curr. ушкодженні, синтезі її компонентів. У неушкодженій рогівці вони перебувають у неактивному стані й активуються при ушкодженні чи запаленні різного генезу. Значна роль у цьому процесі належить матриксним металопротеїназам, які, власне, сприяють ремоделюванню тканини рогівки після ушкодження. Матриксні металопротеїнази - це кальцієзалежні та цинковмісні позаклітинні протеїнази, які також допомагають підтримувати нормальну структуру рогівки. Будь-який збій у високоорганізованому процесі загоєння може призвести до помутніння рогівки, тому теж важливу роль відіграть кальцій та цинк [26].

ВИСНОВОК. Таким чином, результати дослідження розширять і поглиблять існуючі уявлення про елементний склад проби рогівки, видаленої з очей свиней та отриманої методом децелюляризації на вміст макро- і мікроелементів з метою подальшої можливості її застосування як матеріалу для кератопластики.

Eye Res. - 2016. - 41, Issue 6. - P. 769-782. DOI: 10.3109/02713683.2015.1062114.

9. Морфологічні зміни еквівалента строми рогівки, отриманої методом децелюляризації / М.Б.Данилюк, І. М. Кліщ, І. П. Кузьмак, С. Б. Крамар // Мед. та клініч. хімія. - 2020. - 22, № 4 (86). - С. 32-38.

10. Decellularization methods for developing porcine corneal xenografts and future perspectives / A. Isidan, S. Liu, P. Li [et al.] // Xenotransplantation. - 2019. - 26, Issue 6. - e12564. DOI: 10.1111/xen.12564.

11. Acomparison of three methods of decellularization of pig corneas to reduce immunogenicity / W. Lee, Y. Miyagawa, C. Long, [et al.] // Int. J. Ophthalmol. 2014. - 7, Issue 4. - P. 587-593. DOI: 10.3980/j. issn.2222-3959.2014.04.01.

12. Реакция роговицы кролика на интраламеллярную имплантацию бесклеточного модуля стромы роговицы человека / Н. В. Пасечникова, В. В. Вит, Н. Ф. Леус [и др.] // Осртальмол. журн. - 2011. - № 1. C. $57-60$

13. Vabres B. Corneal Xenotransplantation: Anterior Lamellar Keratoplasty / B. Vabres, B. Vanhove, G. Blancho // Method. Mol. Biol. -2020. - No. 2110. -P. 245-251. DOI: 10.1007/978-1-0716-0255-3 16.

14. Науково-практичні рекомендації з утримання лабораторних тварин та роботи з ними / Ю. М. Кожем'якін, О. С. Хромов, М. А. Філоненко, Г. А. Сайфретдінова. - К. : Авіцена, 2002. - 156 с.

15. Пат. на корисну модель № 101707 Україна, МПК (2006.01) А 61 F 9/01, А 61 P 27/02, А 61 N 7/02 (2006.01). Спосіб отримання еквівалента строми рогівки для кератопластики / Коган Б. М., Пасєчнікова Н. В., Насінник І. О., Коломійчук С. Г. ; заявник та патентовласник Держ. установа "Інститут очних 
хвороб і тканинної терапії ім. В. П. Філатова НАМН України". - № u2015032153 ; заявл. 06.04.15 ; опубл. 25.09.15, Бюл. № 18/2015.

16. Брицке М. Э. Атомно-абсорбционный спектрохимический анализ / М. Э. Брицке. - М., 1982. - 375 с.

17. Тарасевич Н. И. Методы спектрального и химико-спектрального анализа / Н.И.Тарасевич, К. А. Семененко, А. Д. Хлыстова. - М. : Изд-во МГУ, 1973. - 276 c.

18. Анализ объектов окружающей среды. Инструментальные методы / под ред. Р. Сониасси ; пер. с англ. - М. : Мир, 1993. - 79 с.

19. Карпов Ю. А. Методы пробоотбора и пробоподготовки / Ю. А. Карпов, А. П. Савостин. - М., 2003. -243 c.

20. МУК 4.1.1471-03. Атомно-абсорбционное определение массовой концентрации ртути в почвах и твердых минеральных материалах : метод. указания [Электронный рерурс]. - Режим доступа: https:// files.stroyinf.ru/Data2/1/4293766/4293766601.htm.

21. ГОСТ 3240.9-76. Сплавы магниевые. Методы определения лантана. - 1982. - 375 с

22. РД 52.24.433-2018. Массовая концентрация кремния в водах. Методика измерений фротометричес- ким методом в виде желтой фрормы молибдокремниевой кислоты (с Поправкой № 1) [Электронный рерурс]. - Режим доступа : https://files.stroyinf.ru/ Index2/1/4293732/4293732924.htm.

23. Турчин М. В. Амінокислотний та елементний склад кріоліофілізованої рогівки свині / М. В. Турчин, В. В. Бігуняк, С. С. Козачок // Фітотерапія. Часопис. 2016. - № 1. - C. 60-64.

24. Агаева Т. С. Изучение свойств микроэлементов, входящих в состав алумена, применяемого в офтальмологии (обзор литературы) / Т. С. Агаева // Офртальмол. журн. - 2011. - 3, № 7. - С. 103-108.

25. Koudouna E. Structural and biochemical investigations of the cornea and the trabecular meshwork: Thesis submitted to Cardiff University for the degree of Doctor of Philosoph / Elena Koudouna. - UK, Cardiff: Cardiff University, 2013. Retrieved from: https://orca. cardiff.ac.uk/56775/1/Koudouna\%20-\%20Elena\%20 -\%20Thesis.pdf.

26. Wilson S. E. Apoptosis in the initiation, modulation and termination of the corneal wound healing response / S. E. Wilson, S. S. Chaurasia, F. W. Medeiros // Exp. Eye Res. -2007. - 85, Issue 3. - P. 305-311. DOI: 10.1016/j.exer.2007.06.009.

\section{REFERENCES}

1. Oliva, M.S., Schottman, T., \& Gulati, M. (2012). Turning the tide of corneal blindness. Indian J. Ophthalmol., 60 (5), 423-427. DOI: 10.4103/0301-4738.100540.

2. Pasyechnikova, N.V., Cogan, B.M., \& Kolomiichuk S.G. (2017). Experimental study of efficacy of intralamellar keratoplasty with corneal stromal substitute developed from decellularized porcine cornea. J. Ophthalmol. (Ukraine), 3, 48-55.

3. Turchin, M.V., \& Pasechnikova, N.V. (2017). Experimental reasons and experience of the use of xenorought in treatment and tectonic cherat plasma in patients with varietes of different etiologies. Hospital Surgery. Journal Named by L. Ya. Kovalchuk, 3, 43-48. DOI: 10.11603/2414-4533.2017.3.8051 [in Ukrainian].

4. McTiernan, C.D., Simpson, F.C., Haagdorens, M., Samarawickrama, C., Hunter, D., Buznyk, O., ..., \& Griffith, M. (2020). LiQD Cornea: Pro-regeneration collagen mimetics as patches and alternatives to corneal transplantation. Sci. Adv., 6 (25), eaba2187. DOI: 10.1126/ sciadv.aba2187.

5. Gain, P., Jullienne, R., He, Z., Aldossary, M., Acquart, S., Cognasse, F., \& Thuret, G. (2016). Global survey of corneal transplantation and eye banking. JAMA Ophthalmol. 134 (2), 167-173. DOI: 10.1001/ jamaophthalmol.2015.4776.

6. Cox, A., \& Zhong, R. (2005). Current advances in xenotransplantation. Hepatobiliary Pancreat. Dis. Int., 4 (4), 490-494.

7. Hara, H., \& Cooper, D.K. (2011). Xenotransplantation - the future of corneal transplantation? Cornea, 30 (4), 371-378. DOI: 10.1097/ICO.0b013e3181f237ef.

8. Wilson, S.L., Sidney, L.E., Dunphy, S.E., Dua, H.S., \& Hopkinson, A. (2016). Corneal decellularization: a method of recycling unsuitable donor tissue for clinical translation? Curr. Eye Res., 41 (6), 769-782. DOI: 10.3109/02713683.2015.1062114.
9. Danyliuk, M.B., Klishch, I.M., Kuzmak, I.P., \& Kramar, S.B. (2020). Morphological changes in the equivalent of the cornea stroma obtained by the deceIularization method. Med. Clin. Chem., 4, 32-38. DOI: $10.11603 /$ mcch.2410-681X.2020.i4.11736 [in Ukrainian].

10. Isidan, A., Liu, S., Li, P., Lashmet, M., Smith, L.J., Hara, H., Cooper, D., \& Ekser, B. (2019). Decellularization methods for developing porcine corneal xenografts and future perspectives. Xenotransplantation, 26 (6), e12564. DOI: 10.1111/xen.12564.

11. Lee, W., Miyagawa, Y., Long, C., Cooper, D. K., \& Hara, H. (2014). A comparison of three methods of decellularization of pig corneas to reduce immunogenicity. Int. J. Ophthalmol., 7 (4), 587-593. DOI: 10.3980/j. issn.2222-3959.2014.04.01.

12. Pasyechnikova, N.V., Vit, V.V., Leus, N.F., Yakimenko, S.A., Buznyk, A.I., \& Nasinnyk, I.O. (2011). The reaction of the rabbit cornea after intralamellar transplantation of the acellular stroma of the human cornea. J. Ophthalmol., 1, 57-60 [in Russian].

13. Vabres, B., Vanhove, B., \& Blancho, G. (2020). Corneal xenotransplantation: anterior lamellar keratoplasty. Method. Mol. Biol., 2110, 245-251. DOI: 10.1007/978-1-0716-0255-3_16.

14. Kozhemiakin,Yu.M., Khromov, O.S., Filonenko, M.A. \& Saifetdinova, H.A. (2002). Scientific and practical recommendations for maintenance laboratory animals and work with them. Kyiv: Avitsenna [in Ukrainian]..

15. Kogan, B.M., Pasechnikova, N.V., Nasinnyk, I.O., \& Kolomiychuk, S.G. (2015). Pat. Ukraine for utility model No. 101707, IPC (2006.01) A 61 F 9/01, A 61 P 27/02, A $61 \mathrm{~N}$ 7/02 (2006.01). The method of obtaining corneal stroma equivalent for keratoplasty. "The Filatov Institute of Eye Diseases and Tissue Therapy of the National Academy of Medical Sciences of Ukraine" 
inventors and assignee. No. u2015032153; stated. 06.04.2015; publ. 25.09.2015, Bull. No. 18/2015 [in Ukrainian].

16. Britske, M.E. (1982). Atomic absorption spectrochemical analysis. Moscow [in Russian].

17. Tarasevich, N.I., Semenenko, K.A., \& Khlystova, A.D. (1973). Methods of spectral and chemicalspectral analysis. Moscow: Publishing House of Moscow State University [in Russian].

18. Soniassi, R. (Ed.). (1993). Analysis of environmental objects. Instrumental methods. Transl. from Engl. Moscow: Mir [in Russian].

19. Karpov, Yu.A., \& Savostin, A.P. (2003). Methods of sampling and sample preparation. Moscow [in Russian].

20. MI 4.1.1471-03. Methodical instructions. Atomic absorption definition. mass concentration of mercury in soils and solid mineral materials. Retrieved from: https:// files.stroyinf.ru/Data2/1/4293766/4293766601.htm [in Russin].

21. (1982). GOST 3240.9-76. Magnesium alloys. Methods for the determination of lanthanum [in Russian].
22. Guidance Document 52.24.433-2018. Mass concentration of silicon in waters. Photometric measurement method in the form of a yellow form of molybdosilicic acid (with Amendment No. 1). Retrieved from: https:// files.stroyinf.ru/Index2/1/4293732/4293732924.htm [in Russian].

23. Turchin, M.V., Bigunyak, V.V., \& Kozachok, S.S. (2016). Amino acid and elemental warehouse of cryoliophilized pig horn. Phytother. J., 1, 60-64 [in Ukrainian].

24. Agaeva, T.S. (2011). Study of properties of the microelements which are a part of the alumen applied in ophthalmology (review of the literature). Oftalmol. J., 3, 7, 103-108 [in Russian].

25. Koudouna, E. (2013). Structural and biochemical investigations of the cornea and the trabecular meshwork. Doctors thesis. UK, Cardiff: Cardiff University. Retrieved from: https://orca.cardiff.ac.uk/56775/1/Koudouna\%20 -\%20Elena\%20-\%20Thesis.pdf.

26. Wilson, S.E., Chaurasia, S.S., \& Medeiros, F.W. (2007). Apoptosis in the initiation, modulation and termination of the corneal wound healing response. Exp. Eye Res., 85 (3), 305-311. DOI: 10.1016/j.exer.2007.06.009.

M. B. Danyliuk ${ }^{1}$, I. M. Klishch ${ }^{1}$, I. P. Kuzmak ${ }^{1}$, A. P. Krasnopyorova ${ }^{2}$ I. HORBACHEVSKY TERNOPIL NATIONAL MEDICAL UNIVERSITY ${ }^{1}$ V. N. KARAZIN KHARKIV NATIONAL UNIVERSITY²

\section{CHEMICAL COMPOSITION OF THE EQUIVALENT OF THE CORNEA STROMA OBTAINED BY THE DECELULARIZATION METHOD}

\section{Summary}

Introduction. As a result of increasing military, traffic and domestic injuries, the problem of shortage of donor material is particularly relevant. The huge shortage of donor material for keratoplasty forces us to look for additional sources of transplant material, methods of making and using xenogeneic grafts. One such material is the pig's cornea, which is similar in structure and biomechanical parameters to the human cornea.

The aim of the study - to research the chemical composition of the equivalent of the corneal stroma, removed from the eyes of pigs and obtained by the method of decelularization in order to further its use as a material for keratoplasty.

Research Methods. The corneal membrane obtained from the removed eyes of pigs is placed in a medium for tissue culture, followed by its decellularization. Treated with $0.5 \%$ solution of sodium dodecyl sulfate with constant shaking; treated with ultrasound (three times), incubate in the presence of an enzyme solution of papain; washed with buffer solution ( $\mathrm{pH}$ 6.5), centrifuged. Place in a solution of polyvinylpyrrolidone for storage. Photocolorimetric and atomic absorption methods of analysis were used to determine the elemental composition of biological samples.

Results and Discussion. The chemical composition of the equivalent of the corneal stroma obtained by the method of decelularization was studied. According to the results of atomic absorption analysis in the decellularized cornea of pig, 14 macro- and microelements were identified. Among macroelements, the largest amount is sodium $8323 \mathrm{mg} / \mathrm{kg}$ of air-dry sample, potassium - $1163 \mathrm{mg} / \mathrm{kg}$, magnesium - $618 \mathrm{mg} / \mathrm{kg}$ and calcium - $224 \mathrm{mg} / \mathrm{kg}$. The mass fraction of microelements in the study object is in the following sequence: iron - $755 \mathrm{mg} / \mathrm{kg}$, cobalt - $296 \mathrm{mg} / \mathrm{kg}$, nickel - $103 \mathrm{mg} / \mathrm{kg}$, titanium - $13.2 \mathrm{mg} / \mathrm{kg}$, zinc - $7.9 \mathrm{mg} / \mathrm{kg}$, manganese $-4.5 \mathrm{mg} / \mathrm{kg}$, silicon - $6.2 \mathrm{mg} / \mathrm{kg}$, copper $5.7 \mathrm{mg} / \mathrm{kg}$, lanthanum $-0.4 \mathrm{mg} / \mathrm{kg}$. The smallest amount is argentum $-0.03 \mathrm{mg} / \mathrm{kg}$.

Conclusion. Promising for further research is a comprehensive study and improvement of the method used to deceleralize the cornea of animals in order to obtain bioengineered samples for their subsequent keratoplasty, which solves the problem of transplantation - obtaining donor material.

KEY WORDS: pig cornea; decellularization; macro- and microelements; atomic absorption method of analysis; keratoplasty.

Отримано 10.11.21

Адреса для листування: І. П. Кузьмак, Тернопільський національний медичний університет імені І. Я. Горбачевського мОз України, майдан Волі, 1, Тернопіль, 46001, Україна, e-mail: kuzmak@tdmu.edu.ua. 